\title{
IMPLEMENTASI PENYUSUNAN LAPORAN KEUANGAN KOPERASI BERDASARKAN PERATURAN MENTERI KOPERASI DAN UMKM REPUBLIK INDONESIA NO.12/PER/M.KUKM/IX/2015 Yeni Hernawati ${ }^{1}$, Dandan Irawan ${ }^{2}$ dan M.Ardi Nupi $\mathbf{H}^{3}$
}

Prodi Akuntansi Keuangan, Fakultas Ekonomi, Institut Manajemen Koperasi Indonesia, Indonesia $^{12 \text { dan } 3}$

Yenihernawati480@gmail.com ${ }^{1}$, irawandandan@gmail.com ${ }^{2}$ dan ardi.nupi@yahoo.com ${ }^{3}$

\begin{abstract}
Abstrak
Latar belakang: Koperasi Pegawai Pemerintah Provinsi Jawa Barat (KPPP) merupakan badan usaha koperasi yang melaksakan kegiatan pada unit usaha Niaga Barang dan Simpan Pinjam. Unit Usaha Niaga Barang merupakan unit usaha yang memberi keuntungan cukup besar bagi Koperasi setiap harinya pendapatan Unit Usaha Simpan Pinjam bisa mencapai 2-3 Juta Rupiah.

Tujuan penelitian: Untuk membangun pondasi akuntansi dalam laporan keuangan.

Metode penelitian: Metode yang dipilih untuk penelitian ini adalah metode dengan studi kasus, dimana studi kasus pada penelitian ini mempelajari secara rinci dan kuat tentang latar belakang suatu fenomena dari keadaan yang diteliti.

Hasil penelitian: Koperasi Pegawai Pemerintah Provinsi Jawa Barat hanya menyajian Neraca dan PHU pada tahun buku 2019. Neraca yang disajikan sudah cukup baik namun masih ada akun yang belum disajikan. Pada Laporan Perhitungan Hasil Usaha koperasi belum memisahkan pendapatan dari anggota dan non anggota sehingga belum dapat dihitung lebih banyak mana manfaat dari anggota atau non anggota.

Kesimpulan: Laporan keuangan yang telah disajikan oleh KPPP Jawa Barat yaitu Neraca dan PHU keseluruhan telah disajikan cukup baik. Pada Laporan neraca telah mecakup 3 (tiga) akun yaitu aset, kewajiban dan modal walaupun masih ada beberapa transaksi yang tidak diakui dan disajikan pada laporan neraca.
\end{abstract}

Kata kunci: Laporan Keuangan, PERMEN, Penyusunan laporan keuangan

\begin{abstract}
Background: The West Java Provincial Government Employee Cooperative (KPPP) is a cooperative business entity that carries out activities in the Goods Trading and Savings and Loans business unit. The Goods Trading Business Unit is a business unit that provides a large enough profit for the Cooperative, the Savings and Loans Business Unit's daily income can reach 2-3 million Rupiah.

Research purposes: To build an accounting foundation in financial statements.

Research methods: The method chosen for this research is the case study method, where the case study in this research studies in detail and strongly about the background of a phenomenon from the circumstances under study..

Research results: The West Java Provincial Government Employee Cooperative only presented the Balance Sheet and PHU for the 2019 financial year. The balance sheet presented was quite good but there were still accounts that had not been presented. In the report on the calculation of operating results, the cooperative has not separated the income from members and non-members so that it cannot be calculated which benefits are more from members or non-members.

Conclusion: The financial reports that have been presented by the West Java KPPP, namely the balance sheet and PHU, have been presented quite well. The balance sheet includes 3 (three) accounts, namely assets, liabilities and capital although there are still some transactions that are not recognized and presented in the balance sheet.

Keywords: Financial Reports, PERMEN, Preparation of financial reports
\end{abstract}

Diterima: 26-12-2021; Direvisi: 29-12-2021; Disetujui: 6-01-2022 


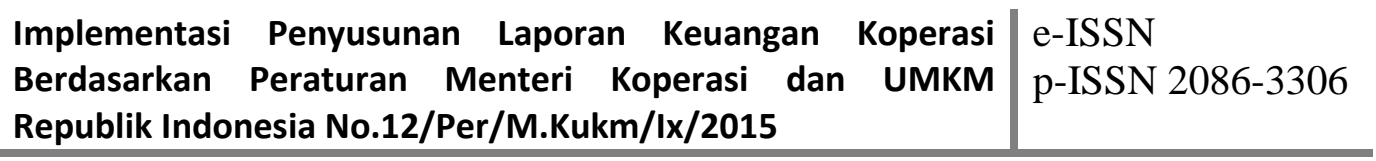

\section{PENDAHULUAN}

Koperasi memiliki prinsip keterbukaan, transparansi serta akuntabilitas yang diakui, diterima dan dipercaya oleh anggota sebagai pengguna jasa koperasi. Indikator terlaksananya prinsip tersebut dapat terlihat melalui proses penyusunan laporan keuangan yang disajikan secara jujur tertib dan wajar (Ikhsan \& Haridhi, 2017). Sebagai badan usaha laporan keuangan merupakan hal yang tidak dapat terpisahkan dengan koperasi. Laporan keuangan koperasi harus memiliki manfaat, baik kepada pengurus, pengawas ataupun anggota (Suyati, 2016). Laporan keuangan digunakan untuk menilai kinerja keuangan koperasi, prestasi unit kegiatan koperasi yang bertugas memberikan pelayanan kepada anggota (Ni'mah, 2011). Selain itu pada tujuan bisnis baik pada anggota maupun non anggota dapat memberikan informasi yang menjelaskan keadaan keuangan koperasi.

Pentingnya laporan keuangan adalah untuk menilai kemajuan atau seberapa besar keuntungan yang diperoleh koperasi, selain itu untuk memudahkan pengurus untuk melakukan pengambilan keputusan demi kemajuan koperasi pada masa yang akan datang. Adapun untuk menilai keuangan koperasi dapat diperoleh melaui neraca, perhitungan hasil usaha, arus kas dan perubahan ekuitas koperasi dan catatan atas laporan keuangan koperasi yang nantinya dapat disampaika kepada anggota untuk pengambilan keputusan koperasi (Nadhiroh \& Indriani, 2019).

Undang-undang nomor 20 tahun 2008 tentang UMKM pasal 23 menyebutkan keterampilan manajerial pada Usaha Mikro Kecil dan Menengah atau UMKM merupakan tanggung jawab untuk dunia usaha dan masyarakat luas. Dampak yang dihadapi dari ketidak mampuan koperasi atau UMKM dalam membuat laporan keuangan yang baik akan memberikan dampak pada tata kelola usaha koperasi dan UMKM yang berpengaruh pada tata kelola badan usaha yang baik atau good corporate governance (GCG) (Wahyuningsih \& Fahmie, 2019).

Pada penerapan akuntansi yaitu penyusunan laporan keuangan diharuskan untuk menerapkan proses pengakuan dan pengukuran (perlakuan), penyajian dan pengungkapan pada setiap transaksi yang terjadi pada kegiatan usaha koperasi. Apabila penyusunan laporan keuangan koperasi tidak mengacu kepada 4 proses tersebut maka laporan keuangan yang disajikan koperasi akan mempengaruhi kinerja keuangan koperasi yang terjadi. Pada koperasi yang bersangkutan (Oktaviyanti et al., 2017).

Koperasi Pegawai Pemerintah Provinsi Jawa Barat (KPPP) merupakan koperasi yang dimiliki oleh pemerintah daerah Provinsi Jawa Barat, koperasi ini menjalankan usaha dibidang Simpan Pinjam dan Niaga Barang, anggota koperasi ini merupakan Aparatur Sipil Negara yang berkedudukan di Organisasi Perangkat Daerah (OPD) yang ada di pemerintahan Provinsi Jawa Barat (Gatot et al., 2017).

Sebagai sebuah entitas yang memiliki tanggung jawab kepada anggota dalam pelaksanaa kegiatan ekonomi, Koperasi Pegawai Pemerintah Provinsi Jawa barat dituntut harus bisa menyusun hingga menyajikan laporan keuangan yang mudah dipahami oleh pengguna baik oleh anggota maupun masyarakat.

Peraturan Menteri Koperasi dan UMKM No.12/per /M.KUKM /IX/2015 menyebutkan koperasi yang bergerak pada bidang sektor riil diharuskan menyajikan laporan keuangan yang mencakup Neraca, Perhitungan Hasil Usaha, laporan perubahan ekuitas arus kas dan Catatan atas laporan keuangan dan juga dalam penyusunan laporan keuangan koperasi belum memiliki sistem akuntansi yang digunkan sebagai pedoman dasar penyusunan laporan keuangan dan masih terdapat beberapa akun yang belum sesuai dengan perlakuan, penyajian juga pengungkapannya. Dampak yang dapat timbul dari 
masalah ini yaitu pada tata kelola koperasi, seperti asas tata kelola koperasi yaitu good coorporate governance (GCG).

\section{METODE PENELITIAN}

Metode yang dipilih untuk penelitian ini adalah metode dengan studi kasus, dimana studi kasus pada penelitian ini mempelajari secara rinci dan kuat tentang latar belakang suatu fenomena dari keadaan yang diteliti. Lalu dengan metode deskriptif dengan tujuan agar mendapatkan informasi dari bagaimana penerapan akuntansi yang terjadi pada penyusunan laporan keuangan koperasi pada akhir tahun buku. Mengetahui bagaimana penyusunan laporan keuangan koperasi berdasarkan pada Peraturan Menteri Koperasi dan UMKM No.12/Per/M.KUKM/IX/2015 tentang koperasi sektor riil.

\section{HASIL DAN PEMBAHASAN}

KPPP Jawa Barat berdiri dengan berlandaskan atas Undang-undang RI No.25 Tahun 1992 tentang perkoperasian. KPPP Jawa Barat merupakan badan usaha yang pelaksanaannya beranggotakan orang-seorang atau badan hukum koperasi, kegiatan yang dilaksanakan berlandaskan pada Undang-undang dan prinsip koperasi sekaligus bergerak sebagai penggerak perekonomian rakyat. Wilayah kerja Koperasi Pegawai Pemerintah Provinsi Jawa Barat adalah meliputi Aparatur Sipil Negara (ASN) yang berada pada Organisasi Perangkat daerah (OPD) yang ada dilingkungan Pemerintah Provinsi Jawa Barat dengan jumlah anggota pada tahun 2020 tercatat sebanyak 1.654 orang.

Usaha perdagangan Umum atau niaga barang adalah untuk memenuhi kebutuhan Primer anggota, seperti Sembako, perabot rumah tangga, sanitasi dan kebutuhan rumah tangga lainnya, Sedangkan kebutuhan sekunder adalah seperti barang-barang dan peralatan audio dan video elektronik dan alat perlengkapan kantor seperti laptop serta alat komunikasi lainnya. Usaha Perdagangan Umum dilaksanakan oleh Unit Niaga Barang yang dipimpin oleh seorang Asisten Manajer Niaga Barang yang bertanggung jawab kepada manajer.

Unit usaha niaga barang/Mini Market cukup memberikan manfaat bagi anggota koperasi serta memberikan kontribusi positif dalam rangka memenuhi kebutuhan anggota. Permodalan usaha perdagangan Umum dilakukan dengan penyetoran modal dari Kas Umum KPPP Jawa Barat yang ditetapkan dalam rapat pengurus dan Badan Pemeriksa setelah mempertimbangkan Proposal Kegaitan usaha yang diajukan oleh manajer. Namun dalam pelaksanaan usaha niaga barang terdapat beberapa catatan auditor yaitu:

1. Kurangnya upaya yang sistematis dan berkelanjutan dalam rangka memaksimalkan upaya pengelolaan penjualan barang pada unit usaha niaga barang maka dari itu pada unit usaha ini perlu dilaksanakan pencatatan secara hati-hati, cermat dan akuntabel.

2. Pengurus Unit Usaha Niaga Barang belum melakukan perhitungan transaksidan pendapatan dari piutang niaga barang serta hasil operasional mini market secara cermat dan akuntabel.

3. Pengurus diharuskan memberikan laporan dan penjelasan dalam forum rapat anggota tahunan atas adanya penurunan omzet penjualan usaha niaga barang/mini market dan pendapatan hasil penjualan tersebut secara rinci dan akuntabel. 


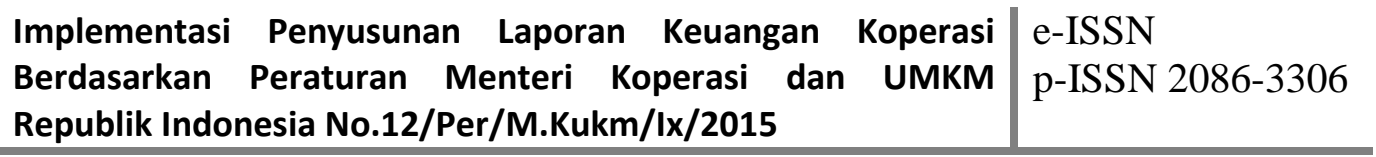

4. Pengadaan Barang dan Jasa serta Jasa Rekanan Usaha Pengadaan Barang dan Jasa serta Jasa Rekanan adalah kegiatan pengadaaan barang dan jasa serta rekanan yang dilaksanakan berdasarkan permintaan (order), baik pesanan perorangan maupun secara kelembagaan (instansi pemerintah atau organisasi perangkat daerah di lingkungan pemerintah provinsi jawa barat yang nilainya diatas Rp.25.000.000 (keterangan pada tahun 2010).

Usaha perdagangan Barang dan Jasa serta Jasa rekanan diselenggarakan oleh Unit Operasional yang dipimpin oleh Asisten Manajer Operasional. Yang bertanggung jawab kepada manajer. Permodalan kegiatan pengadaan Barang dan Jasa dilakukan dengan penyetoran modal dari kas Umum KPPP Jawa Barat yang ditetapkan dalam rapat pengurus dan Badan Pengawas setelah mempertimbangkan proposal kegiatan yang diajukan oleh manajer.

Kegiatan jasa rekanan dapat diselenggarakan oleh Manajer KPPP Jawa Barat sendiri dan/atau kegiatan yang bersifat kemitraan dengan pihak ketiga yang diatur dalam perjanjian kerjasama. Permodalan kegiatan usaha Jasa Rekanan dilakukan dengan penyetoran modal dari Kas Umum KPPP Jawa Barat dan/ atau modal bersama dengan pihak ketiga yang labanya diperhitungkan secara "bagi hasil" (profite sharing) yang tertuang dalam perjanjiian kerjasama atau kemitraan Usaha.

Laporan keuangan merupakan hasil kegiatan usaha selama suatu periode akuntansi. Tujuan laporan keuangan adalah untuk mengetahui status keuangan suatu entitas dan memberikan informasi mengenai status keuangan, kinerja dan perubahannya (Arief, 2016). Informasi ini berguna untuk perkembangan entitas perusahaan. Saat menyusun laporan keuangan, tentunya ada standar dan pedoman penyusunan. Panduan ini digunakan untuk membuat semua laporan keuangan perusahaan menjadi handal dan mudah dipahami.

Peraturan Menteri dan Koperasi dan UMKM No.12/Per/M.KUKM/IX/2015 tentang pedoman umum akuntansi sektor riil, menyebutkan bahwa laporan keuangan mencakup neraca, perhitungan hasil usaha, laporan perubahan ekuitas, laporan arus kas dan Catatan atas laporan keuangan.

Adapun sistem yang digunakan dalam menyusun laporan keuangan khususnya unit usaha niaga barang menggunakan aplikasi MYOB dalam membantu menyusun semua transaksi yang ada hingga menjadi laporan keuangan periodik. Untuk pedoman yang masih digunakan oleh koperasi adalah PSAK 27. Laporan keuangan yang disusun oleh KPPP Jawa Barat telah mengikuti standar akuntansi untuk koperasi. Laporan keuangan disusun dengan dasar akrual (Juanda \& Nauli, 2018).

Keseuaian Penyusunan laporan keuangan Koperasi berdasarkan Peraturan Menteri Koperasi dan UMKM No. 12 Tahun 2015 Tentang Pedoman Akuntansi Sektor Riil Laporan keuangan Unit Usaha Niaga Barang KPPP Jawa Barat dievaluasi sesuai dengan Peraturan Menteri Koperasi dan UMKM No.12/Tahun 2015 tentang standar akuntansi entitas. Komponen laporan keuangan KPPP Jawa Barat meliputi laporan keuangan unit perdagangan Barang KPPP Jawa Barat.

Laporan keuangan merupakan hasil kegiatan usaha selama suatu periode akuntansi. Tujuan laporan keuangan adalah untuk mengetahui status keuangan suatu entitas dan memberikan informasi mengenai status keuangan, kinerja dan perubahannya. Informasi ini berguna untuk perkembangan entitas perusahaan. Saat menyusun laporan keuangan, tentunya ada standar dan pedoman penyusunan. Panduan ini digunakan untuk membuat semua laporan keuangan perusahaan menjadi handal dan mudah dipahami.Peraturan Menteri dan Koperasi dan UMKM No.12/Per/M.KUKM/IX/2015 tentang pedoman umum akuntansi sektor riil, menyebutkan bahwa laporan keuangan mencakup neraca, 
perhitungan hasil usaha, laporan perubahan ekuitas, laporan arus kas dan Catatan atas laporan keuangan. Adapun sistem yang digunakan dalam menyusun laporan keuangan khususnya unit usaha niaga barang menggunakan aplikasi MYOB dalam membantu menyusun semua transaksi yang ada hingga menjadi laporan keuangan periodik. Untuk pedoman yang masih digunakan oleh koperasi adalah PSAK 27. Laporan keuangan yang disusun oleh KPPP Jawa Barat telah mengikuti standar akuntansi untuk koperasi. Laporan keuangan disusun dengan dasar akrual.

Keseuaian Penyusunan laporan keuangan Koperasi berdasarkan Peraturan Menteri Koperasi dan UMKM No. 12 Tahun 2015 Tentang Pedoman Akuntansi Sektor Riil

Laporan keuangan Unit Usaha Niaga Barang KPPP Jawa Barat dievaluasi sesuai dengan Peraturan Menteri Koperasi dan UMKM No.12/Tahun 2015 tentang standar akuntansi entitas. Komponen laporan keuangan KPPP Jawa Barat meliputi laporan keuangan unit perdagangan Barang KPPP Jawa Barat.

Neraca merupakan laporan yang memberikan informasi tentang status keuangan suatu unit usaha pada tanggal tertentu. Informasi status keuangan ini diolah berdasarkan jumlah aset yang dimiliki (disebut aset dan total kewajiban) (Riswan \& Kesuma, 2014). Neraca unit usaha niaga barang secara terpisah mencantumkan komponen aset, kewajiban dan ekuitas. Menjelaskan penerapan masing-masing komponen aset, kewajiban dan ekuitas dalam hal penanganan, penyajian dan pengungkapan. Rincian aset yang disajikan KPPP Jawa Barat pada Neraca belum semuanya sesuai dengan Permenkop No.12 tahun 2015. Aset tetap Koperasi memiliki Aset Tetap berupa, tanah, bangunan mesin dan kendaraan. namun Koperasi hanya mengakui sebagai aset dan tidak menghitung masingmasing nilai aset yang dimiliki koperasi. Penyajian aset tetap tersebut belum sesuai karena tidak mencerminkan harga perolehan yang sebenarnya dimiliki koperasi.

Akumulasi penyusutan aset tetap. Pengakuan dan Pengukuran: Bertambahnya penyusutan untuk setiap periode diakui sebagai beban untuk periode yang bersangkutan dan nilainnya disesuaikan dengan metode penyusutan aset koperasi yang bersangkutan.

Aset tidak berwujud lain, Koperasi memiliki Aset tidak berwujud yaitu software yang merupakan sistem yang ada pada bagian kasir sistem yang mengendalikan jumlah stock barang di bagian pencatatan. Namun koperasi belum mengakui adanya transaksi tersebut. Aset tidak berwujud, tidak disajikan sebagai aset pada neraca. Tidak ada catatan atas laporan keuangan yang menjelaskan informasi mengenai aset tidak berwujud tersebut. Koperasi tidak mengakui adanya akumulasi amortisasi aset tidak berwujud. Pada tahun 2019 terjadi penjualan aset berupa kendaraan yang dimiliki oleh KPPP Jawa Barat. Namun hal tersebut tidak diungkapkan bagaimana penjualannya dan apakah terdapat kerugian dari penjulan kendaraan tersebut.

Aset tetap lain, koperasi memiliki aset tetap yaitu berupa penunjang sarana dan prasarana operasional. KPPP juga memiliki penyelesaian piutang atas penyimpangan dari penjualan BBM pada tahun 2016 yang hingga saat ini masih belum diselesaikan namun transaksi ini disajikan sebagai aset tetap koperasi. Pos aset tetap lain disajikan pada pos aset tetap lain pada neraca. Pada tahun buku 2019 tidak ada catatan atas laporan keuangan yang menjelaskan rincian atau informasi yang menjelaskan aset tetap apa saja yang digunakan sebagai penunjang sarana dan prasarana tersebut.

Kewajiban imbalan pasca kerja, koperasi memiliki transaksi imbalan pasca kerja yaitu salah satu bentuk penyisihan dana yang diperuntukan sebagai dana prestasi/imbalan/pesangon bagi pengurus dan pengelola yang melakukan aktivitas yang menguntungkan koperasi. Namun belum diakui sebagai transaksi dan dinilai sebesar niali nominalnya. Pada tahun buku 2019 tidak ada catatan atas laporan keuangan yang menjelaskan rincian jumlah atau saldo dari kewajiban imbalan pasca kerja. 
Perhitungan hasil usaha adalah penyertaan yang menggambarkan hasil usaha koperasi selama suatu periode akuntansi. Komponen perhitungan kinerja usaha meliputi pendapatan jasa kepesertaan, pendapatan usaha bukan anggota, sisa total kinerja operasional, beban operasional, pendapatan lain- lain atau beban lainnya, pajak perusahaan dan sisa kinerja operasional setelah pajak.

Implementasi dari laporan perhitungan usaha KPPP Jawa Barat sudah sesuai walaupun masih ada kekurangan yaitu, Pendapatan dari pelayanan anggota, khususnya pada unit usaha niaga barang koperasi tidak menjelaskan pendapatan yang berasal dari pelayanan anggota, ataupun non anggota, serta rincian dan informasi dari pendapatan dari pelayanan anggota karena pada setiap hasil penjualan tidak dipisahkan baik dari anggota maupun non anggota. Sedangkan pada unit usaha niaga barang untuk anggota koperasi diperbolehkan untuk menggambil kredit dengan bunga 10-15\% tergantung dari jumlah kreditnya, sedangkan untuk non anggota tidak diperkenankan untuk mengambil kredit di koperasi. Pendapatan dari kredit tersebut bisa digolongkan pendapatan dari pelayanan anggota.

Pendapatan dari bisnis dengan non Anggota, pada unit uaha niaga barang khususnya pada toko, koperasi tidak menjelaskan pendapatan yang berasal dari bisnis dengan non anggota (Tionaomi, 2017). Karena setiap orang yang datang ke unit usaha niaga barang tidak dipisahkan apakah itu anggota atau tidak, maka dari itu KPPP Jawa Barat tidak menjelaskan penjualan barang/jasa kepada non anggota, yaitu pendapatan koperasi yang timbul dari transaksi bisnis dengan pihak non anggota.

Sisa Hasil Usaha Kotor, telah disajikan pada laporan perhitungan hasil usaha. Beban operasional, telah disajikan pada laporan perhitungan hasil usaha. Pendapatan dan atau beban lainnya telah disajikan pada laporan perhitungan hasil usaha. Beban Pajak telah disajikan pada laporan perhitungan hasil usaha dan sisa hasil usaha setelah pajak telah disajikan pada perhitugan hasil usaha.

Laporan perubahan ekuitas adalah laporan yang memberikan informasi tentang laba rugi koperasi saat ini, pos-pos pendapatan dan beban yang langsung dimasukan dalam ekuitas periode berjalan, dampak kebijakan akuntansi dan koreksi kesalahan yang diakui dalam periode ini. KPPP Jawa Barat tidak memberikan laporan perubahan ekuitas pada akhir periode saat ini. KPPP Jawa Barat juga dalam proses penyusunan laporan keuangan koperasi dilakukan proses konfirmasi dan pengukuran (processing), penyajian dan pengungkapan.

Laporan arus kas merupakan semua arus masuk ataupun arus keluar uang tunai kas atau setara kas. Arus kas memiliki fungsi sebagai penyedia informasi tentang perubahan uang tunai pada koperasi yang dilaporkan pada komponen yang terpisah, pada pelaksanaanya KPPP Jawa Barat tidak menyajikan laporan arus kas pada akhir periode tahun buku, namun pada hasil wawancara dengan asisten manajer bidang administrasi dan keuangan menjelaskan bahwa laporan arus kas disusun dengan metode tidak langsung dan arus kas dikelompokan atas dasar aktivitas operasi, investasi, dan pendanaan. Untuk tujuan laporan arus kas, kas dan setara kas mencakup kas, bank dan investasi jangka panjang.

Pada proses penyusunan laporan keuangan koperasi dilakukan proses pengakuan dan pengukuran (perlakuan), penyajian dan pengungkapan. Pengungkapan merupakan pemberian informasi tambahan yang dibutuhkan untuk menjelaskan unsur-unsur pos/akun (perkiraan) kepada pihak yang berkepentingan sebagai catatan dalam laporan keuangan koperasi. Catatan atas laporan keuangan koperasi harus memuat pengungkapan kebijakan koperasi yang mengakibatkan perubahan perlakuan akuntansi dan pengungkapan informasi lainnya. Namun pada pelaksannya KPPP Jawa Barat belum membuat catatan 
atas laporan keuangan, sehingga informasi yang ada belum belum cukup untuk menjelaskan unsur-unsur pos/akun yang dimiliki oleh koperasi.

Penerapan akuntansi dan penyusunan laporan keuangan, koperasi melakukan proses pengakuan dan pengukuran (perlakuan), penyajian dan pengungkapan pada setiap transaksi dan estimasi pos-pos akuntansi yaitu :

a. Pengakuan

Pengakuan yaitu proses penetapan rekening dengan nilai atau biaya yang terukur dalam neraca atau laporan perhitungan hasil usaha (PHU) dimana manfaat ekonomi yang terkait dengan perkiraan akan mengalir kedalam badan usaha koperasi.

b. Pengukuran

Pengukuran adalah proses penentuan jumlah mata uang yang digunakan oleh koperasi untuk mengukur nilai aset, kewajiban, pendapatan dan bebanpada laporan keuangan koperasi.

c. Penyajian

Penyajian adalah proses penempatan posisi/akun (perkiraan) secara tepat dan wajar dalam laporan keuangan.

d. Pengungkapan

Pengungkapan adalah konfirmasi tambahan yang diperlukan untuk menjelaskan unsur-unsur akun/rekening (estimasi) kepada pemangku kepentingan laporan keuangankoperasi sebagai catatan atas laporan keuangan.

\section{KESIMPULAN}

Berdasarkan penelitian didapatkan kesimpulan Laporan keuangan yang telah disajikan oleh KPPP Jawa Barat yaitu Neraca dan PHU keseluruhan telah disajikan cukup baik. Pada Laporan neraca telah mecakup 3 (tiga) akun yaitu aset, kewajiban dan modal walaupun masih ada beberapa transaksi yang tidak diakui dan disajikan pada laporan neraca. Perhitungan Hasil Usaha (PHU) telah mencakup 3 (tiga) akun yaitu pendapatan, beban dan sisa hasil usaha, namun pada penyajiannya akun masih terdapat perbedaan penamaan dan juga belum memisahkan antara transaksi bisnis dengan anggota dan transaksi bisnis dengan non anggota. Laporan keuangan yang disajikan masih menyatu dengan unit usaha lain yaitu usaha simpan pinjam,

Sistem akuntansi yang ada pada KPPP Jabar belum sepenuhnya terbentuk, masih ada beberapa hal yang harus diperbaiki misalanya dokumen yang mendukung untuk penyusunan laporan keuanga. Sistem pencatatan atas kejadian ekonomi yang terjadi pada KPPP Khusunya untuk unit usaha niaga barang. KPPP Jabar juga mengalami kemunduran pada hal penyusunan laporan keuangan, tidak terjadi kelengkapan laporan dari tahun sebelumnya dikarenakan sibuknya pengawas, pengurus koperasi untuk memeriksa keadaan koperasi.

\section{BIBLIOGRAFI}

Arief, R. (2016). Peran Audit Internal Atas Kualitas Pemeriksaan Laporan Keuangan yang Dilakukan oleh Audit Eksternal pada sebuah Perusahaan. Jurnal Ekonomi Universitas Esa Unggul, 7(01), 78768.

Gatot, D., Supardal, D., Nasution, F. G. A., \& IP, S. (2017). Naskah Akademik: Raperda Tentang Penguatan Usaha Mikro Dan Ekonomi Kreatif.

Ikhsan, A., \& Haridhi, M. (2017). Penerapan standar akuntansi keuangan Syariah pada koperasi jasa keuangan Syariah (studi pada baitul qiradh di kota Banda Aceh). Syiah Kuala University.

Juanda, A., \& Nauli, P. (2018). Pengaruh Proses Reviu Laporan Keuangan Terhadap Kualitas 
Laporan Keuangan Pemerintah Daerah dengan Pemahaman Standar Akuntansi Pemerintah sebagai Variabel Moderasi. Jurnal Akuntansi Dan Keuangan, 23(1), 1-48.

Nadhiroh, U., \& Indriani, S. R. (2019). Penyusunan Laporan Keuangan Berdasarkan Sak Etap Pada Koperasi Wanita "Usaha Bersama." JAE (Jurnal Akuntansi Dan Ekonomi), 4(2), 3346.

Ni'mah, U. (2011). Analisis Kinerja Keuangan pada Koperasi BMT Bina Usaha Kecamatan Bergas Kabupaten Semarang. Universitas Negeri Semarang.

Oktaviyanti, P. M., Herawati, N. T., AK, S. E., Atmadja, A. T., \& SE, A. (2017). Pengaruh pengendalian internal, kompetensi sumber daya manusia, dan budaya etis organisasi terhadap kualitas laporan keuangan (studi kasus koperasi simpan pinjam di Kecamatan Buleleng). JIMAT (Jurnal Ilmiah Mahasiswa Akuntansi) Undiksha, 8(2).

Riswan, R., \& Kesuma, Y. F. (2014). Analisis laporan keuangan sebagai dasar dalam penilaian kinerja keuangan PT. Budi Satria Wahana Motor. Jurnal Akuntansi Dan Keuangan, 5(1).

Suyati, E. S. (2016). Pengelolaan Manajemen Koperasi Sekolah. Pedagogik: Jurnal Pendidikan, $11(2), 88-96$.

Tionaomi, R. T. (2017). Laporan Praktik Kerja Lapangan Pada Unit Usaha Simpan Pinjam Dan Toko Di Koperasi Pegawai Kementerian Perdagangan Niaga Sejahtera Jakarta Pusat.

Wahyuningsih, D., \& Fahmie, A. (2019). Rancangan model tata kelola keuangan umkm berbasis teknologi informasi dan komunikasi. IKRA-ITH HUMANIORA: Jurnal Sosial Dan Humaniora, 3(3), 83-92.

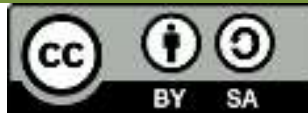

This work is licensed under a Creative Commons Attribution-ShareAlike 4.0 International License 